\title{
Optimalisasi Distribusi Surat Suara Pemilu pada Pemilihan Umum Serentak
}

\author{
Resista Vikaliana $^{1, *}$, I Nyoman Purnaya ${ }^{2}$ \\ ${ }^{1}$ Institut Ilmu Sosial dan Manajamen STIAMI, Jakarta, Indonesia \\ ${ }^{2}$ Institut Ilmu Sosial dan Manajamen STIAMI, Jakarta, Indonesia \\ ${ }^{1}$ resistav31@gmail.com*; ${ }^{2}$ npurnaya@gmail.com \\ * corresponding author
}

\section{ARTICLE INFO}

\section{Article history}

Received 2019-10-23

Revised

Accepted 2019-12-06

Keywords

Ballot Papers

2019 Simultaneous Elections

Distribution

\begin{abstract}
The purpose of this study is to determine the process of ballot distribution and propose a model of the optimal ballot distribution process. This research is useful in providing input on the distribution of ballot papers for the first time this election is held simultaneously. The input is expected to increase effectiveness in the distribution or distribution of ballots so that they can produce good ballots when needed by the parties concerned. This study uses a qualitative approach with in-depth interviews with key informants, observation and documentation studies. The distribution model on the 2019 Simultaneous Election ballots is to be implemented in stages. For overseas distribution, in order to reduce distribution costs, enable digital signatures, and eVote, because the internet infrastructure is more adequate.
\end{abstract}

\section{PENDAHULUAN}

Pemilihan Umum merupakan amanat Pembukaan Undang-Undang Dasar Negara Republik Indonesia tahun 1945. Sesuai dengan amanat tersebut, UU no 7 tahun 2017 tentang pemilihan umum mengatur pemilihan umum sebagai perwujudan sistem ketatanegaraan yang demokratis dan berintegritas demi menjamin konsistensi dan kepastian hokum serta pemilihan umum yang efektif dan efisien. (Rahadian, Vikaliana, \& Saputra, 2019).

Partisipasi dalam pemilihan umum adalah salah satu bentuk partisipasi politik dan merupakan partisipasi paling dasar dalam demokrasi. Partisipasi politik adalah tindakan sukarela; warga negara biasa biasanya melakukannya untuk mempengaruhi keputusan publik . Partisipasi adalah tindakan, alih-alih keinginan, niat, minat atau kemauan. Partisipasi dalam pemilihan umum dan pemilihan presiden dengan memilih partai atau kandidat adalah salah satu bentuk partisipasi politik, termasuk dalam pemilihan presiden. (Fuad, 2014).

Selain etika penyelengaraaan pemilu yang harus dijaga (Lestari, 2015), penyelenggaraan pemilu perlu didukung manajemen logistik yang baik. Logistik pemilu, seperti tertulis dalam banyak literatur kepemiluan adalah alat untuk mengkonversi suara menjadi kursi. Logistik pemilu di banyak negara disebut juga sebagai election material. Berbeda dengan proses distribusi logistik pelaksanaan kegiatan nasional lainnya, logistik pemilu adalah sarana penting dalam perhelatan besar demokrasi yang melibatkan banyak orang dan banyak jalur. Tiga proses pasokan logistik utama yang berlangsung dalam pemilu atau pilkada saat ini adalah proses pengadaan, distribusi, dan penarikan logistik. Tidak bisa tidak, ketiga elemen tersebut adalah kunci utama kesuksesan penyelenggaraan pemilu yang genuine dan berintegritas. (Barkati, 2014).

Logistik pemilu yang baik meminimalisir surat suara yang rusak, sehingga tidak sampai mengulang produksi surat suara. Surat suara yang diterima di KPU Daerah, melalui proses sortir, pengecekan, dan pelipatan. Setelah itu, akan disimpan di gudang KPU daerah sebelum nantinya disalurkan ke tempat pemungutan suara (TPS) minimal sepekan sebelum pencoblosan/ Pemilu berlangsung. Setiap logistik yang tiba di TPS harus dalam keadaan tersegel. Personil kepolisian dan TNI membantu untuk mengamankan distribusi dari gudang perusahaan, ke KPU kabupaten dan kota, hingga ke TPS.

Negara Indonesia yang merupakan negara kepulauan, menjadi pertimbangan yang mendasar pada proses distribusi surat suara. Terdapat 67 daerah prioritas distribusi. Daerah-daerah ini menjadi prioritas karena banyak memiliki kendala di akses transportasi dan cuaca ekstrem yang bisa mengganggu proses 
pengiriman. Selain kabupaten-kabupaten di Papua, daerah kepulauan seperti Nias dan Sumba menjadi prioritas distribusi logistik.

Proses pengadaan dalam siklus pemilu meliputi pengadaan jasa dan pengadaan barang. Tidak seperti instansi lain, beberapa item barang dan jasa dalam proses pemilu sangat spesifik, sehingga tidak semua perusahaan dapat menyediakan. Secara garis besar, proses pengadaan barang dan jasa pemilu terbagi atas dua tahapan; pertama, logistik pada persiapan pemilu, dan logistik pada pelaksanaan pemilu. Sedangkan barang dan jasa yang harus disiapkan pra pelaksanaan pemilu di antaranya adalah aplikasi dan software untuk pengolahan data pemilih, data yang berkaitan dengan peserta pemilu, serta aplikasi yang berhubungan dengan proses penghitungan suara supaya dapat diakses oleh publik. Seluruh aplikasi ini tidak akan berjalan dengan baik jika infrastruktur kerasnya tidak disiapkan. Artinya, seluruh penyelenggara pemilu sampai level kabupaten kota harus memiliki perangkat keras yang diperlukan, seperti scanner supercepat, dan komputer dengan spek tertentu yang kompatibel dengan aplikasi yang digunakan. (Guru, Dasar, \& Matematika, 2009)

Tahapan selanjutnya adalah pengadaan barang yang digunakan pada hari $\mathrm{H}$ pemilu. Di antara barang yang harus ada dalam tempat pemungutan suara adalah kotak dan bilik suara, alat coblos atau penanda surat suara, surat suara, tinta, dan surat suara untuk penyandang disabilitas netra. Dari daftar tersebut, beberapa item dapat dilaksanakan menggunakan mesin modern, dengan harga yang terstandar. Tapi, alat coblos dan bantalannya, serta surat suara untuk pemilih dengan disabilitas adalah item khusus yang hanya dimiliki oleh penyedia barang tertentu. Seluruh proses pengadaan ini akan lancar jika tahapan pemilunya direncanakan dengan baik.

\section{Tujuan Penelitian}

Tujuan Penelitian ini adalah untuk mengetahui proses distribusi surat suara dan mengusulkan sebuah model proses distribusi surat suara yang optimal.

Manfaat Penelitian ini adalah memberikan masukan terhadap distribusi surat suara pada Pemilu yang untuk pertama kali dilakukan serentak ini. Masukan tersebut diharapkan dapat meningkatkan efektifitas dalam penyaluran atau distribusi surat suara sehingga dapat menghasilkan surat suara yang yang baik pada saat diperlukan oleh pihak-pihak yang terkait.

\section{TINJAUAN PUSTAKA}

\section{Pemilu Serentak}

Penyelenggaraan pemilu selama ini, di mana penyelenggaraan pemilu untuk memilih anggota DPR, DPD dan DPRD yang terpisah dengan pemilu, berdampak pada besarnya beban KPU Pusat sementara KPU di daerah hanya menjadi pelaksana teknis saja. Sedangkan jika pemilu diselenggarakan serentak, namun terpisah antara nasional dan lokal, maka beban menjadi relatif lebih tertata dan merata. Untuk Pemilu Nasional Serentak, beban KPU Pusat hanya mengurusi surat suara pada level nasional. Sementara untuk Pemilu Lokal Serentak, KPU di tingkat provinsi menjadi penanggung jawab pengadaan surat suara di wilayahnya. Dengan model seperti ini, kemungkinan surat suara tertukar sangat minim karena pada Pemilu Nasional Serentak, KPU RI hanya akan mengirimkan surat suara ke 77 Dapil untuk surat suara calon anggota DPR dan ke 34 provinsi. Sementara untuk penyelenggaraan Pemilu Lokal Serentak, KPU provinsi hanya bertanggung jawab untuk melakukan pengadaan surat suara dan distribusi logistik pemilu untuk provinsinya.

Dari sisi pengaturan waktu, persiapan pemilu yang dimulai sejak dua tahun sebelum penyelenggaraan pemilu nasional serentak akan membuat persiapan pemilu lebih leluasa dan program-program sosialisasi dapat dilaksanakan lebih baik. Untuk penyelenggaraan pemilu lokal serentak yang dilaksanakan dua setengah tahun setelah pemilu nasional serentak juga akan memberi waktu yang cukup bagi penyelenggara untuk menyiapkannya.

\section{Logistik Pemilu}

Logistik adalah perlengkapan pemungutan suara dan dukungan perlengkapan lainnya. Proses pengepakan logistik dan pendukung lainnya seperti sortir dan lipat surat suara yang dilaksanakan di tingkat KPU Kabupaten/ Kota harus mempedomani SOP yang ditetapkan sekretaris jendral KPU dengan memperhatikan kondisi wilayah yang bersangkutan, agar lebih efektik dan efisien dalam pelaksanaannya.

Guna mendukung kelancaran sistem penyaluran kotak suara dan surat suara, maka perlu dibuat suatu sistem yang dapat memberikan layanan dan kemudahan bagi proses penyaluran kotak suara dan surat suara. 
Hal ini penting sekali mengingat setiap proses kegiatan yang dilakukan nantinya harus dilaporkan dalam pelaksanaannya. Laporan tersebut sangat dibutuhkan oleh pihak KPU provinsi sebagai bahan masukan dalam mengambil keputusan. Menurut Triyanto, tujuan pelaksanaan sistem penyaluran kotak suara dan surat suara tersebut adalah:

a. Memberikan layanan guna mempermudah dan memperlancar proses pelaksanaan pemilu.

b. Membantu kelancaran prosedur penyaluran kotak suara dan surat suara sehingga menjadi lebih efektif.

c. Sebagai alat bantu bagi pihak yang terlibat dalam mengawasi pelaksanaan pemilu. (Atma \& Pangkalpinang, 1998)

\section{METODE PENELITIAN}

Penelitian ini menggunakan pendekatan kualitatif dengan wawancara mendalam dengan key informan, observasi dan studi dokumentasi. Penelitian ini hanya memfokuskan pada Pemilu Serentak 2019, tidak melingkupi pemilu -pemilu sebelumnya. Key informan dari penelitian ini adalah 2 Petugas KPU dan 3 petugas KPPS.

\section{HASIL DAN PEMBAHASAN}

Berdasarkan hasil penelitian, berikut ini merupakan gambar distribusi logistik pemilu pada Pemilu Serentak 2019.

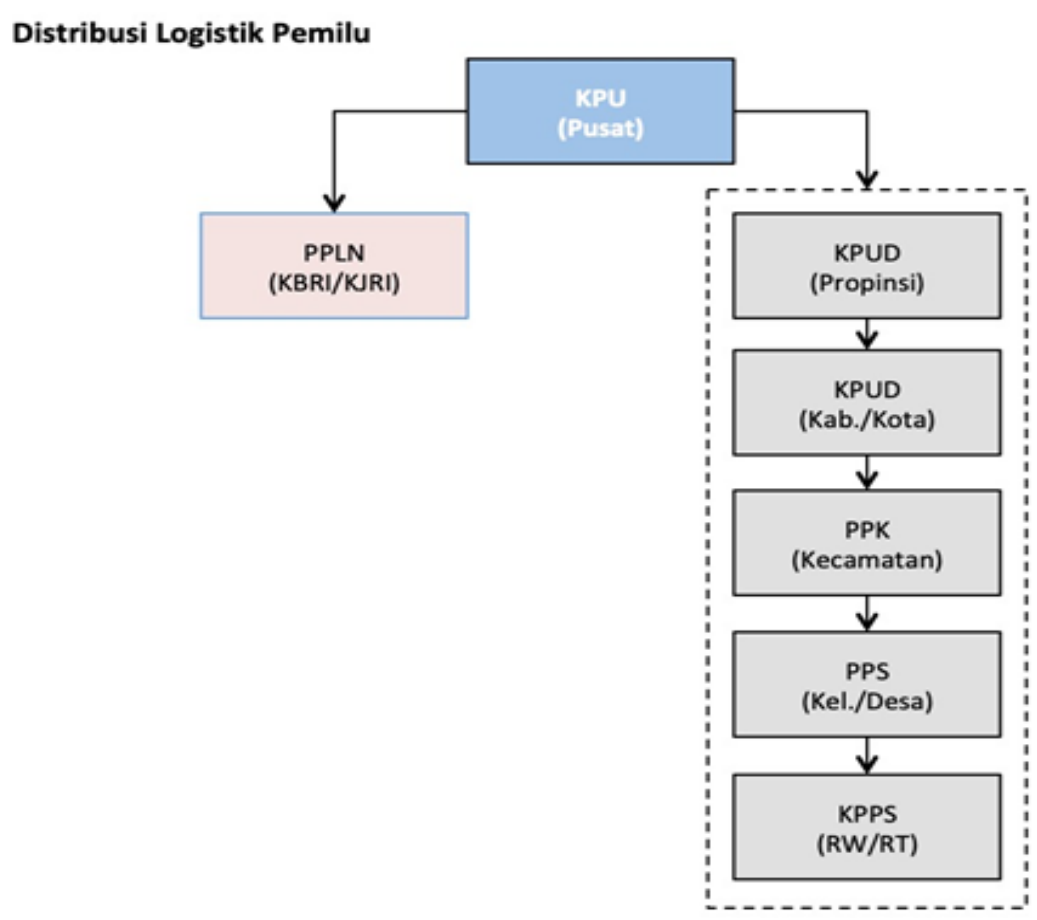

Gambar 1. Distribusi Logistik Pemilu Serentak 2019

Berdasarkan gambar di atas, sebagai representasi hasil penelitian, distribusi surat suara dibagi menjadi dua bagian besar, yakni Distribusi ke Luar Negeri dan Distribusi ke Dalam Negeri.

Distribusi ke dalam negeri dilakukan dengan mempergunakan moda transportasi darat, laut maupun sungai. Alur pendistribusian logistic pemilu dalam negeri pada Pemilu Serentak 2019 dilakuan berjenjang, dari KPUD / Komisi Pemilihan Umum Daerah di Tingkat Propinsi hingga KPPS/ Kelompok Panitia Pemungutan Suara di tingkat RT/ RW. Penghitungan biaya distribusi dihitung keseluruhan hingga tingkat kelurahan/ desa.

Distribusi ke Luar Negeri dilakukan dengan menggunakan angkutan udara (door to door), melalui kantor Kedutaan Besar Republik Indonesia/ KBRI atau Konsulat Jenderal Republik Indonesia/ KJRI. Penghintungan biaya distribusi dilakukan door to door, mulai dari KPU sampai ke KBRI/ KJRI. 
Berdasarkan hasil penelitian, bagi Pemilu di luar negeri, agar dapat mengurangi biaya distribusi, dapat dilakukan melalui tanda tangan digital dan eVote. Tanda tangan secara digital dan eVote, berpeluang besar diterapkan pada Pemilu di luar negeri, karena infrastruktur internet sangat memadai.

Dalam proses adopsi teknologi informasi (TI) tersebut, kepercayaan memiliki dampak yang penting. Penelitian Fathul Wahid dkk telah menguji faktor-faktor penentu kepercayaan politisi dalam penggunaan TI dalam pemilihan umum. Berdasarkan survei di antara 120 politisi lokal dalam konteks Indonesia, penelitian tersebut menemukan bahwa kualitas institusi dan kualitas informasi memiliki dampak signifikan pada kepercayaan politisi, sedangkan kualitas sistem dan kualitas layanan tidak. Studi tersebut mengungkapkan bahwa faktor-faktor pra-interaksional (diwakili oleh kualitas institusional) dan faktor interaksional (tercermin dalam kualitas informasi) memiliki dampak langsung yang signifikan terhadap pembangunan kepercayaan di antara para politisi terhadap penggunaan TI dalam pemilihan umum. Dua variabel ini menjelaskan 67\% dari total varian kepercayaan. (Wahid \& Prastyo, 2013)

\section{SIMPULAN DAN SARAN}

\section{Simpulan}

1. Model istdribusi pada surat suara pemilu Serentak 2019 adalah dilakukan secara berjenjang.

2. Untuk distribusi ke luar negeri, agar dapat mengurangi biaya distribusi, memungkinkan secara tanda tangan digital, dan eVote, karena infrastruktur internet lebih memadai.

\section{Saran}

Berdasarkan hasil penelitian, maka disarankan untuk

1. Menerapkan Block Chain Technology:

Untuk menjamin surat suara terdistribusi dengan baik, dengan memantau keterlusuran/ keterlacakannya, teknologi 4.0, dalam hal ini blockchain technology. Sebagai tahap berikutnya dari penelitian ini, adalah mengidentifikasi tingkat penerimaan penerapan atau implementasi dari blockchain technology.

2. Membuat Standar Pergudangan Logistik Pemilu

Pergudangan merupakan salah satu hal penting dalam proses distribusi surat suara Pemilu. Dalam proses distribusi, diperlukan standar minimal kriteria untuk gudang yang layak untuk menyimpan surat suara, sebelum didistribusikan ke tingkat KPPS.

\section{DAFTAR PUSTAKA}

Atma, S., \& Pangkalpinang, L. (1998). Penyaluran Kotak Dan Surat Suara.

Barkati, Z. I. (2014). kabupaten malinau, 1-11.

Fuad, A. B. B. (2014). Political Identity and Election in Indonesian Democracy: A Case Study in Karang Pandan Village - Malang, Indonesia. Procedia Environmental Sciences, 20, 477-485. https://doi.org/10.1016/j.proenv.2014.03.060

Guru, P., Dasar, S., \& Matematika, P. (2009). Peningkatan Kualitas Penyelenggaraan Pemilihan Umum Proporsional, Akuntabilitas Dan Efektif Melalui Sistem Pemilu Online Dengan Autentikasi E-Ktp, 1, $42-52$.

Lestari, S. B. (2015). Jurnal Ilmu Sosial. Jurnal Ilmu Sosial, 14(2), 24-41. Retrieved from https://ejournal.undip.ac.id/index.php/ilmusos/article/view/10364/8241

Rahadian, A. ., Vikaliana, R., \& Saputra, M. (2019). Substansi Perubahan Sistem Pemilu Dan Implikasinya Berdasarkan Undang-Undang Nomor 7 Tahun 2017 Tentang Pemilihan Umum Serta RKPD Tahun 2018 Sesuai Permendagri Nomor 32 Tahun 2017 (Pendampingan Bimbingan Teknis Nasional Anggota DPRD Kota Sungai Penuh). Jurnal Komunitas Jurnal Pengabdian Masyarakat, 2(1), 32-37. Retrieved from http://ojs.stiami.ac.id/index.php/jks/article/view/290

Wahid, F., \& Prastyo, D. (2013). Politicians' Trust in the Information Technology Use in General Election: Evidence from Indonesia. Procedia Technology, 11(Iceei), 374-379. https://doi.org/10.1016/j.protcy.2013.12.205 